\title{
Effect of Temperature on the Water Injection Bacteria in Basrah Oilfields, Southern Iraq
}

\author{
Rasha A. Al-Ali ${ }^{1}$, Hayder K. Almayyahi ${ }^{2 *}$, Hussein Saeed Almalikee ${ }^{1}$, Zainab M. Abdul- \\ Wahhab $^{1}$ \\ ${ }^{1}$ Basrah University, College of Science - Geology Department. \\ ${ }^{2}$ BasrahOil Company, Ministry of Oil
}

*Corresponding Author: Hayder K. Almayyahi, BasrahOil Company, Ministry of Oil

\begin{abstract}
Bacterial activities had an effect on petroleum industry through producing of $\mathrm{H}_{2} \mathrm{~S}$, within reservoirs or top facilities, which reduce oil quality, corrode steel material, and threatened workers' health due to its high toxicity. The main source of bacteria is water that injected inside the oil reservoirs. Most of the southern Iraqi oil field such as Rumaila, Zubair, and West Qurna are using hat Al-Arab water for injection to increase the reservoirs pressure and push oil towards production wells. The water of Shat Al-Arab contains a large amounts of bacteria and fungi. Therefore, during water treatment chlorine is added to the water in Qarmat Ali pump station to eliminate the bacteria, this process is costly especially with huge amounts of water. In this study a simple analysis of Shat Al-Arab water was conducted by applying gradual heat to the water sample simulating the increase of temperature with depth in oil wells, from monitoring temperature effect on bacteria, it was found that the Shatt al-Arab water bacteria can be killed at $70^{\circ} \mathrm{C}$, and injection water may not require chlorine.
\end{abstract}

\section{INTRODUCTION}

The waters of Shatt Al-Arab, may have originated from aquatic biogenic sources; i.e., diatoms, algal forms, bacterial activities, and higher plants. In the oil industry, water flooding or water injection is where water is injected into the reservoir. Water injection wells can be found on both onshore and offshore, to increase oil recovery from an existing reservoir, throughout supporting reservoir pressure (also known as void age replacement), and also to sweep or displace oil from the reservoir, pushing it towards the production wells. Normally only $30 \%$ of the oil in a reservoir can be extracted, but water injection increases that percentage (known as the recovery factor) and maintains the production rate of a reservoir over a longer period. Water injection involves drilling injection wells into a reservoir and introducing water into that reservoir to encourage oil production. While the injected water helps to increase depleted pressure within the reservoir, it also helps to move the oil in place, it is important that the water being injected works within the formation. Filtration and processing of the water that will be injected are sometimes necessary to ensure that no materials clog the pores and bacteria are not permitted to grow. Oxygen should be removed from the water to reduce any corrosion in surface facilities and subsurface tubing and casing. Surface water contains bacteria that can contaminate the water-treatment or injection systems. Because bacteria have the ability to multiply rapidly into colonies, they can cause plugging of surface and downhole equipment and injection-well formations, promote corrosion of surface piping and downhole tubular, and generate $\mathrm{H}_{2} \mathrm{~S}$ that can cause pitting corrosion. Therefore, it is essential to develop means to control bacteria growth in surface-watertreatment system.

\section{STUdy AREA AND METHOdOLOGY}

Two sampling locations were selected on Shatt Al-Arab river along the region extending from Qarmat-Ali in Basrah governorate, southern Iraq (Figure 1). Replicate water samples were collected by water collector device from each station during 2018winter season; the samples were then transferred to laboratory in sterile bottles. For best results and accuracy, the sample was analyzed by two laboratories, first, in College of Science laboratory in Basrah University and second, in sample was analyzed in Marine Sciences Center, University of Basrah. 


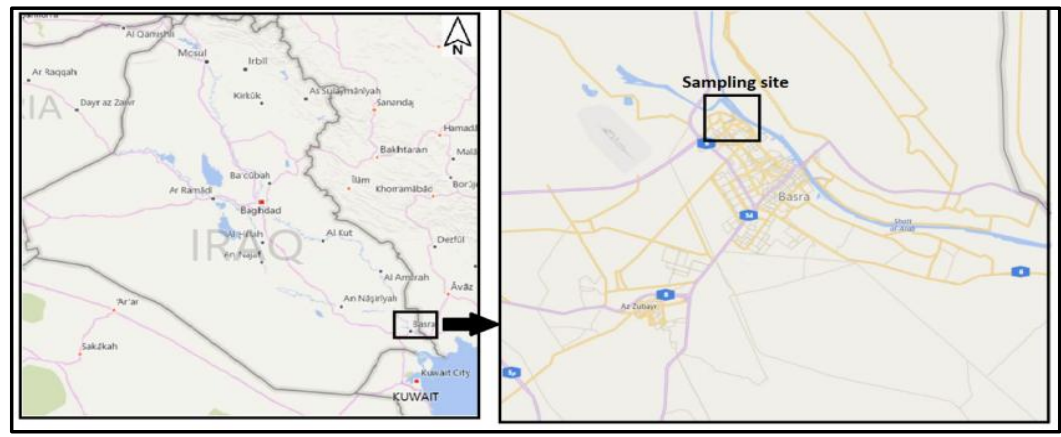

Fig1. Study area and sampling site

\section{RESUltS}

Petroleum biodegradation occur in the reservoir when temperature is within limits that support life and microorganisms that are capable of degrade hydrocarbons must be present. Furthermore, there must be sufficient access to petroleum electron acceptors, water with salinity $<100-150$ parts per thousand must be present, and the rock fabric must have sufficient porosity and permeability to allow bacterial mobility and diffusion of nutrients (Bata, 2016; Peters, 2005). Reservoir temperature is an important factor that limits biodegradation, studies have shown that microbial degradation of petroleum is optimal at surface or near-surface temperatures and that it has an upper limit of $\sim 60$ $80^{\circ} \mathrm{C}$. At temperatures above $80^{\circ} \mathrm{C}$, most bacteria cease to metabolize. However, some thermophilic bacteria have been reported to survive at temperatures as high as about $110^{\circ} \mathrm{C}$ (Bata, 2016; Peters, 2005).

Analysis result showed that all types of bacteria were killed in temperatures between $\left(60^{\circ}-70^{\circ}\right) \mathrm{C}$ (Table 1 and 2)

Table1. Sample analysis (College of Science laboratory, University of Basrah)

\begin{tabular}{|c|c|c|c|c|}
\hline Bacteria & No. of Bacteria/100ml & Temperature & Time $(\mathrm{min})$ & Temperature for Killing \\
\hline Total Bacteria & *Uncountable & $60^{\circ}-65^{\circ}$ & $30-15$ & $70^{\circ} \mathrm{C}$ \\
\hline Total Staphylococcus & Uncountable & $60^{\circ}-65^{\circ}$ & $30-15$ & $70^{\circ} \mathrm{C}$ \\
\hline Total E. coli & Uncountable & $60^{\circ}-65^{\circ}$ & $30-15$ & $70^{\circ} \mathrm{C}$ \\
\hline Total Coliform & Uncountable & $60^{\circ}-65^{\circ}$ & $30-15$ & $70^{\circ} \mathrm{C}$ \\
\hline Total Fecal Coliform & Uncountable & $60^{\circ}-65^{\circ}$ & $30-15$ & $70^{\circ} \mathrm{C}$ \\
\hline Total Pseudomonas & Uncountable & $60^{\circ}-65^{\circ}$ & $30-15$ & $70^{\circ} \mathrm{C}$ \\
\hline $\begin{array}{c}\text { Bacillus \& spore } \\
\text { forming Bacteria }\end{array}$ & -- & & 5 & $121^{\circ} \mathrm{C}$ \\
\hline
\end{tabular}

Table2. Sample analysis (Marine Science Center laboratory, University of Basrah)

\begin{tabular}{|c|c|c|c|}
\hline Sample No. & No. of Bacteria/100ml@ $45^{\circ}$ & No. of Bacteria/100ml@ $50^{\circ}$ & No. of Bacteria $/ 100 \mathrm{ml} @ 70^{\circ}$ \\
\hline 2 & $5^{*} 10^{-3}$ & $3^{*} 10^{-3}$ & Nil \\
\hline
\end{tabular}

Most of the world's petroleum reserves are biodegraded and strong indirect evidence indicates that indigenous anaerobic bacteria of oil fields are mainly responsible for this process (Head, 2003; Roling, 2003; Aitken, 2004). Enrichments and isolation experiments performed with samples collected from low and high temperature reservoirs revealed the presence of physiologically diverse microbial communities and led to the characterization of numerous microorganisms, including both litho autotrophic and chemoorganoheterotrophic strains. The resident anaerobic bacteria include sulfate-reducers (Cord-Ruwish, 1987; Voordouw, 1991; Voordouw, 1992; Tardy-Jacquenod, 1996; Leu, 1998), fermentative bacteria (Bonch-Osmolovskaya, 2003), iron reducers (Slobodkin, 1999), acetogens (Hermann, 1992) and methanogens (Ollivier, 1997) (for a review, see (Magot, 2000)). Recent applications of molecular techniques allowed more complete characterizations of the microbial assemblages inhabiting a low-temperature water flooded Canadian reservoir (Voordouw,1996) and high-temperature, sulfur-rich oil-bearing formations in California and in Siberia (Orphan, 2000). The latter studies have extended our view of microbial communities in reservoirs and suggested the potential for closely coupled biogeochemical cycling of carbon and sulfur in these saline petroleum systems.

Nevertheless, our current knowledge of the diversity and in situ activities of the microorganisms present in these particular subsurface ecosystems is still limited. Depending on the physicochemical 
characteristics of the reservoir rock, the major terminal processes are supposed to be either sulfatereduction or methanogenesis (Head, 2003; Magot, 2000) but the predominant carbon sources used by microorganisms are not well defined. Although several anaerobic alkane- or aromatic compounddegraders have been enriched or isolated from anaerobic surface environments (Hobbie, 1997), the microbial mechanisms, the rates and location of in situ hydrocarbon degradation are not yet understood. Moreover, various geochemical substrates such as organic acids or hydrogen are present in oil reservoirs (Morita, 2000) and are likely to support growth of many anaerobic microorganisms. To better understand the complex oilfield food chain, there is a necessity to enlarge our knowledge of oilfield communities by integrating geochemical and physicochemical data with both molecular and culture-based microbial analyses. During the last decade, the complementary use of molecular and cultural methods has proven effective to characterize microbial assemblages from high-temperature $\left(>70^{\circ} \mathrm{C}\right)$ and saline petroleum reservoirs (Orphan, 2000). However, no comparable studies have been reported in low-temperature and freshwater petroleum reservoirs.

A field expedition was organized to sample production waters in a low-salinity, low-temperature biodegraded reservoir that had not been subjected to water injection. The purpose of this study was to analyze the microbial community associated with the Pelican Lake oilfield (Western Canadian Sedimentary Basin) by using a multidisciplinary approach, including chemical and geochemical analyses, biodegradation studies, culture-based and molecular phylogenetic approaches.

\section{CONCLusion}

Both surface and produced water contain bacteria that can contaminate the water-treatment or injection systems. Because bacteria have the ability to multiply rapidly into colonies, they can cause plugging of surface and downhole equipment and injection-well formations, promote corrosion of surface piping and downhole tubular, and generate $\mathrm{H}_{2} \mathrm{~S}$ that can cause pitting corrosion. Therefore, it is essential to develop means to control bacteria growth in surface-water-treatment system. But it's observed that temperature that exceeds $60^{\circ} \mathrm{C}$ can kill bacteria, this temperature is available at current Mishrif reservoir $\left(76^{\circ} \mathrm{C}\right)$ and Zubair reservoir $\left(99^{\circ} \mathrm{C}\right)$. In this case, according to the results obtained there is an indicator that temperature of Basrah oil fields reservoirs are capable to terminate the risk of bacteria coming from Shatt Al-Arab water that used in injection.

\section{REFERENCES}

[1] Bata, T. Parnell, J. Bowden, S. (2016). Origin of Heavy Oil in Cretaceous Petroleum Reservoirs. Bull Can Pet Geol 64: 106-118

[2] Bata, T. (2016). Geochemical Consequences of Cretaceous Sea Level Rise. Unpublished PhD thesis submitted to the Department of Geology and Petroleum Geology, University of Aberdeen.Available from: http://ethos.bl.uk/OrderDetails.do?uin=uk.bl.ethos.690589

[3] Peters KE, Walters CC, Moldowan JM (2005). The Biomarker Guide: Biomarkers and isotopes in petroleum exploration and Earth history, v. 2. Biomarkers Isot Pet Syst Earth Hist Ed 2: 490

[4] Head, I.M., Jones, D.M. and Larter, S.R. (2003). Biological activity in the deep subsurface and the origin of heavy oil. Nature 426, 344-352.

[5] Roling, W.F.M., Head, I.M. and Larter, S.R. (2003). The microbiology of hydrocarbon degradation in subsurface petroleum reservoirs: perspectives and prospects. Res. Microbiol. 154, 321-328.

[6] Aitken, C.M., Jones, D.M. and Larter, S.R. (2004).Anaerobic hydrocarbon biodegradation in deep subsurface oil reservoirs. Nature 431, 291-294

[7] Cord-Ruwish, R., Kleinitz, W. and Widdel, F. (1987).Sulfatereducing bacteria and their activities in oil production. J. Petrol.Technol. 1987, 97-106.

[8] Tardy-Jacquenod, C., Caumette, P., Matheron, R., Lanau, C.,Arnauld, O. and Magot, M. (1996). Characterization of sulfatereducing bacteria isolated from oil-field waters. Can. J. Microbiol.42, 259-266.

[9] Leu, J.Y., McGovern-Traa, C.P., Porter, A.J.R., Harris, W.J. andHamilton, W.A. (1998) Identification and phylogenetic analysis ofthermophilic sulfate-reducing bacteria in oil field samples by 16SrDNA gene cloning and sequencing. Anaerobe 4, 165-174

[10] Bonch-Osmolovskaya, E.A., Miroshnichenko, M.L., Lebedinsky,A.V., Chernyh, N.A., Nazina, T.N., Ivoilov, V.S., Belyaev, S.S.,Boulygina, E.S., Lysov, Y.P., Perov, A.N., Mirzabekov, A.D.,Hippe, H., Stackebrandt, E., LHaridon, S. and Jeanthon, C.(2003).Radioisotopic, culture-based, and oligonucleotide microchip analyses of thermophilic microbial communities in a continental high-temperature petroleum reservoir. Appl. Environ. Microbiol. 69, 6143-6151. 
[11] Slobodkin, A.I., Jeanthon, C., LHaridon, S., Nazina, M., Miroshnichenko, M. and Bonch-Osmolovskaya, E. (1999). Dissimilatory reduction of Fe(III) by thermophilic bacteria and archaea in deep subsurface petroleum reservoirs of Western Siberia. Curr. Microbiol. 39, 99-102

[12] Hermann, M., Vandecasteele, J.P. and Ballerini, D. (1992). Anaerobic microflora of oil reservoirs Microbiological characterization of samples from some production wells In: Bacterial Gas (Vially, R., Ed.), pp. 223-234. Editions Technip, Paris.

[13] Ollivier, B., Cayol, J.L., Patel, B.K.C., Magot, M., Fardeau, M.L. and Garcia, J.L. (1997). Methanoplanus petrolearius sp. nov., a novel methanogenic bacterium from an oil-producing well. FEMS Microbiol. Lett. $147,51-56$.

[14] Magot, M., Ollivier, B. and Patel, B.K.C. (2000). Microbiology of petroleum reservoirs. Anton. Leeuw. 77, 103-116.

[15] Voordouw, G., Armstrong, S.M., Reimer, M.F., Fouts, B., Telang, A.J., Shen, Y. and Gevertz, D. (1996). Characterization of $16 \mathrm{~S}$ rRNA genes from oil field microbial communities indicates the presence of a variety of sulfate-reducing, fermentative, and sulfide-oxidizing bacteria. Appl. Environ. Microbiol. 62, $1623-1629$

[16] Orphan, V.J., Taylor, L.T., Hafenbradl, D. and Delong, E.F. (2000). Culture-dependent and cultureindependent characterization of microbial assemblages associated with high-temperature petroleum reservoirs. Appl. Environ. Microbiol. 66, 700-711

[17] Hobbie, J.E., Daley, R.J. and Jasper, J. (1977). Use of nuclepore filters for counting bacteria by fluorescence microscopy. Appl. Environ. Microbiol. 33, 1225-1228

[18] Morita, R.Y. (2000). Is $\mathrm{H}_{2}$ the universal energy source for longterm survival?.Microb. Ecol. 38, 307-320

Citation: Rasha A. Al-Ali, et.al. (2019)'"Effect of Temperature on the Water Injection Bacteria in Basrah Oilfields, Southern Iraq", Southeast Cameroon, International Journal of Mining Science (IJMS), 5(1), pp.22-25, DOI: http://dx.doi.org/10.20431/2454-9460.0501003

Copyright: (C) 2019 Authors. This is an open-access article distributed under the terms of the Creative Commons Attribution License, which permits unrestricted use, distribution, and reproduction in any medium, provided the original author and source are credited 